\title{
Medical teacher : how much they are satisfied with their job?
}

\author{
Rawshan Ara Khanam ${ }^{\prime}$, Humayun Kabir Talukder ${ }^{2}$,Tahmina Nargis ${ }^{3}$, Abdul Wohab Khan ${ }^{4}$, SM Idris Ali ,Abdal Mia , Afrin \\ Rubaiyat ${ }^{6}$, Tawhidur Rahman', Golam Rabbi ${ }^{8}$, Wakil Ahmed ${ }^{9}$
}

\begin{abstract}
Job satisfaction includes the fulfillment of both extrinsic and intrinsic satisfaction dimensions.. To find out the views of medical teachers regarding their job satisfaction this study was carried out in 10 medical colleges for one year among 218 teachers working in preclinical, paraclinical and clinical departments of those medical colleges. Structured questionnaire using 47 characters related to job satisfaction were compiled under 8 themes. Among these for 39 questions 5 point Likert scale was used as rating scale. For satisfaction or dissatisfaction 3 was taken as the cut off value. Mean age of the respondents were 42 years and they passed 3 years after last promotion, $41 \%$ teachers were female, $87 \%$ were married and $81 \%$ had post graduate degrees. Among the 8 themes teachers were highly satisfied with all of the 4 items under theme 1 ( relation with others). Teachers were also satisfied with theme 2 (teaching related responsibilities )\& theme 3 ( teaching environment) though level of satisfaction was not very high. Teachers were not satisfied with activities related to current work ie, theme 4 but highly dissatisfied with the facilities available other than the salary ( theme5). Regarding local administration medical teachers were highly dissatisfied (theme 6) but there was low level satisfaction with central administration (theme7). Regarding clinical teachers satisfaction all teachers were highly satisfied with all the items (theme 8). Satisfaction with one or other aspect of their job was $58.6 \%$ which was not very high. Low salary, adverse environment, political interference in posting promotion was the most important cause for dissatisfaction.
\end{abstract}

\section{Introduction}

Job satisfaction includes the fulfillment of both extrinsic and intrinsic satisfaction dimensions. The extrinsic sources of satisfaction are situational which depends on pay, promotion, job security, working environment etc. Intrinsic sources of satisfaction depends on ability to use initiatives, interpersonal relationship and work itself ${ }^{1}$.In recent years despite all about the job contract over all job satisfaction is declining. In Europe over all job satisfaction is $80 \%$. Job satisfaction keeps falling in UK and USA. ${ }^{2}$ For medical teachers intrinsic satisfaction can came from class room activities, daily interaction with students, students learning from their teaching. Professional autonomy enhances the

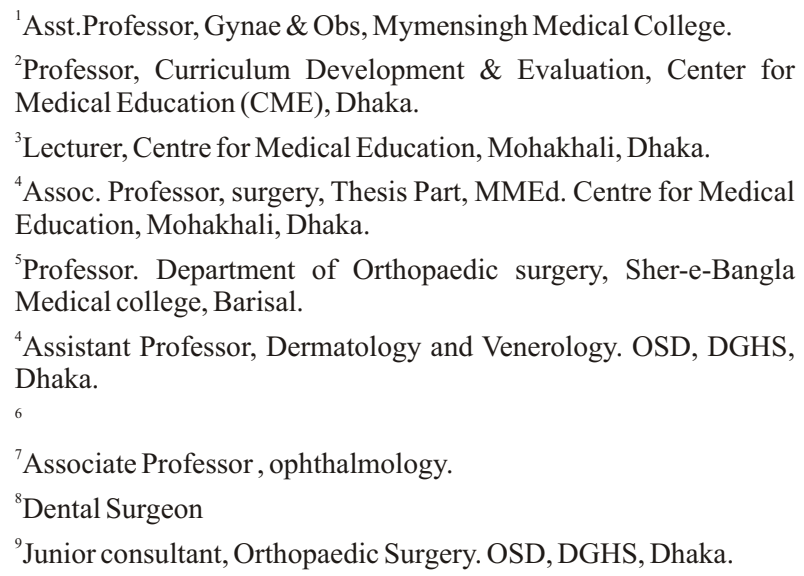

Address of correspondence: Rawshan Ara Khanam, Asst. Professor, Gynae \& Obs, Mymensingh Medical College. attractiveness of teaching profession and improves the class room performance. Intrinsic factors plays role for motivating peoples for teaching profession. Most of the teachers enjoys teaching and wants to work with the young peoples. Very few teachers enter in to teaching for external rewards like- salary, prestige or benefits. However internal factors motivate peoples to become teacher but external factors influences their satisfaction ${ }^{3}$. Studies of medical professors show that, teaching is considered secondary to the medical profession, i.e. teaching is not considered a profession in its own right. Senior teachers are involved with teaching the clinical rounds, clinical training, patient care etc. and are generally qualified in their specific areas of technical performance which is their focus. ${ }^{4}$ Among many methods for measuring job satisfaction, the most common for collecting data is the Likert scale.

\section{Research Question}

What are the views among medical teachers regarding their job satisfaction?

\section{General objective}

To find out the views of medical teachers regarding their job satisfaction.

\section{Methodology}

It was a cross sectional type of descriptive study done in 10 medical colleges of which 5 were public medical college and 5 nongovernment medical colleges situated in Dhaka city and out side for one year (July 2011 to June 2012). Study population were two hundred and eighteen teachers working in preclinical, Para clinical and clinical departments of those medical colleges. Sampling technique was convenience

Bangladesh Journal of Medical Education 2011;2(1):18-22. (C) 2011 Ara et al., publisher and licensee Association of Medical Education. This is an Open Access article which permits unrestricted non-commercial use, provided the original work is properly cited. 
sampling. Those who were willing to participate were included in this study. Self-administered, pretested, structured, anonymous, using English ,questionnaires with Likert scale was ued for collecting data. There were 47 items. Among these items, 8 items were the variables measuring the general characters. Other 39 items were included in structured questionnaires. Each of the 39 items had 5 point Likert scale. All the collected data has been checked manually. Data editing, entry, processing and analysis has been done by using 15 version of SPSS. For clear understanding of the result, the information of structured questionnaires were grouped into 8 themes. There was no ethical problem because all the information has been collected anonymously with prior permission of the authority and all the participants has given their opinion voluntarily. Researcher maintained confidentiality in all cases.

\section{Results}

Table 1 : Distribution of the respondents by their general and service related information $(\mathrm{n}=218)$

\begin{tabular}{|l|c|}
\hline Characters & No. ( \%) \\
\hline Male & $128(59 \%)$ \\
Female & $90(41 \%)$ \\
Married & $190(87 \%)$ \\
Unmarried & $28(13 \%)$ \\
Post graduate & $176(81 \%)$ \\
Graduate & $37(17 \%)$ \\
Age ( mean age) & 42.37 years \\
Mean length of service(years) & 13.18 years \\
Mean period passed after last & 3.08 years \\
promotion (years) & \\
\hline
\end{tabular}

Table showing that $41 \%$ teachers were female , $87 \%$ were married and $81 \%$ had post graduate degrees. Mean age of the respondents were 42 years and they passed 3 years after last promotion.

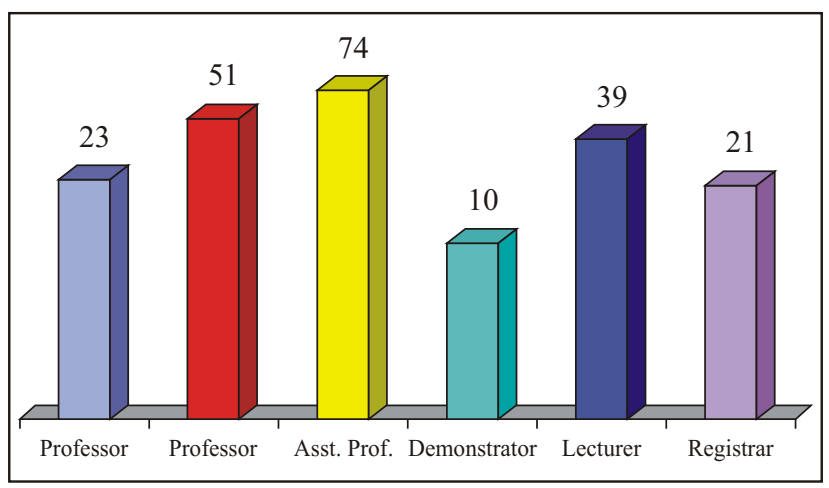

Graph I : Distribution of the respondents as per designation

Among the respondents 74(34\%) were Assistant Professors,
$23(11 \%)$ were Professors and $51(23 \%)$ were Associate Professors. Demonstrator were 10 ( 5\%), Lecturer were 39 ( $18 \%$ ) and Registrar were 21 ( 10\%).

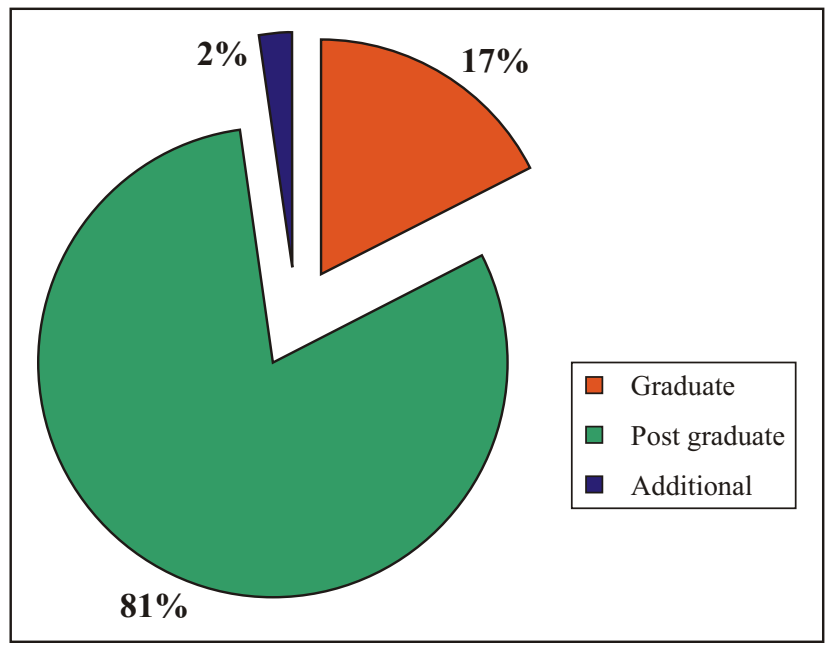

Graph II: Distribution of the respondents as per their educational level

Postgraduate teachers were of $81 \%$, graduate teachers comprises about $17 \%$ and additional post graduate degrees comprises $2 \%$.

Table 2: Distribution of mean score and SD of level of satisfaction with different items in relation to relation with others

\begin{tabular}{|l|c|c|c|}
\hline $\begin{array}{l}\text { 1. Themes and items } \\
\text { of teaching related } \\
\text { satisfaction }\end{array}$ & $\boldsymbol{N}$ & Mean & Std. Deviation \\
\hline Relation with others: \\
\hline $\begin{array}{l}\text { Relation with } \\
\text { colleagues (Senior) }\end{array}$ & 213 & 3.94 & .986 \\
\hline $\begin{array}{l}\text { Relation with } \\
\text { colleagues (Peer) }\end{array}$ & 207 & 4.25 & .670 \\
\hline $\begin{array}{l}\text { Relation with } \\
\text { colleagues (Junior) }\end{array}$ & 208 & 4.24 & .809 \\
\hline $\begin{array}{l}\text { Teacher student } \\
\text { relationship }\end{array}$ & 217 & 3.71 & 1.039 \\
\hline Total mean of 4 items & \multicolumn{3}{|c|}{1614} \\
\hline
\end{tabular}

Table showing the theme relation with others had 4 items with total mean score 16.14 .Cut off value was 12 . Total mean was more than the cut off value, which indicated that teachers were satisfied in this theme.

Table 3: Distribution of mean score and SD of level of satisfaction with different items in relation to teaching related responsibilities. 


\begin{tabular}{|l|c|c|c|}
\hline $\begin{array}{l}\text { Teaching related } \\
\text { responsibilities : }\end{array}$ & N & Mean & STD \\
\hline Independence in work & 211 & 3.19 & 1.213 \\
\hline Responsibilities within teaching & 211 & 3.10 & 1.140 \\
\hline $\begin{array}{l}\text { Being creative and taking new } \\
\text { challenge }\end{array}$ & 205 & 2.89 & 1.197 \\
\hline $\begin{array}{l}\text { Making contribution to } \\
\text { educational development }\end{array}$ & 203 & 2.94 & 1.172 \\
\hline $\begin{array}{l}\text { Attitude of the student regarding } \\
\text { their learning }\end{array}$ & 216 & 3.26 & 1.052 \\
\hline $\begin{array}{l}\text { Extent of support to the } \\
\text { innovative ideas in teaching }\end{array}$ & 211 & 2.72 & 1.156 \\
\hline $\begin{array}{l}\text { Supportive to the co-curricular } \\
\text { activities }\end{array}$ & 199 & 3.10 & 1.155 \\
\hline Total mean of 7 items & \multicolumn{3}{|c|}{21.20} \\
\hline
\end{tabular}

Table 3 showing the Teaching related responsibilities which had 7 items with cut off value 21 . Total achieved mean was 21.20. Total mean was slightly more than the cut off value. It mean that teachers were not un satisfied in this theme.

Table 4: Distribution of mean score and SD of level of satisfaction with different items in relation to teaching environment.

\begin{tabular}{|l|c|c|c|}
\hline Teaching environment: & N & Mean & STD \\
\hline Physical environment of institution & 217 & 3.71 & 1.025 \\
\hline Physical environment of classroom & 215 & 3.31 & 1.085 \\
\hline $\begin{array}{l}\text { Supplies and maintenance of } \\
\text { necessary educational materials }\end{array}$ & 217 & 2.82 & 1.132 \\
\hline Satisfaction with place of posting & 209 & 3.50 & 1.119 \\
\hline Total mean of 4 items & \multicolumn{3}{|c|}{13.34} \\
\hline
\end{tabular}

Table 4 showing the item wise mean score and total mean score of teaching environment. This theme had 4 items with cut off value 12 . Total achieved mean score was 13.34 which was more than the cut off value. It indicated teachers satisfaction in this theme.

Table 5: Distribution of mean score and SD of level of satisfaction with different items in relation to work related satisfaction.

\begin{tabular}{|l|c|c|c|}
\hline Work related satisfaction: & N & Mean & STD \\
\hline With current work/work itself & 218 & 3.67 & 1.025 \\
\hline Current salary status & 217 & 2.86 & 1.198 \\
\hline $\begin{array}{l}\text { Opportunity for professional } \\
\text { development of teachers }\end{array}$ & 217 & 2.77 & 1.214 \\
\hline Undue pressure at work place & 201 & 2.69 & 1.152 \\
\hline Total mean of 4 items & \multicolumn{4}{|c|}{11.99} \\
\hline
\end{tabular}

Table 5 showing the work related satisfaction. This theme had 4 items with cut off value 12 . Total achieved mean was which 11.99 which was less than the cut off value indicating teachers dissatisfaction in this theme.

Table 6: Distribution of mean score and SD of level of satisfaction with different items in relation to facilities enjoyed.

\begin{tabular}{|l|c|c|c|}
\hline Facilities enjoyed: & N & Mean & STD \\
\hline Residence & 166 & 2.87 & 1.389 \\
\hline Transport & 168 & 2.63 & 1.387 \\
\hline Telephone & 162 & 2.78 & 1.419 \\
\hline Other monitory facility & 163 & 2.23 & 1.240 \\
\hline On job training & 170 & 2.26 & 1.227 \\
\hline Total mean of 5 items & \multicolumn{3}{|c|}{12.77} \\
\hline
\end{tabular}

Table 6 showing the facilities enjoyed other than the salary. This theme had 5 items with cut off value 15 .Total achieved mean was 12.77 which was much less, that indicated teachers strong dissatisfaction regarding this theme.

Table 7: Distribution of mean score and SD of level of satisfaction with different items in relation to local administration.

\begin{tabular}{|c|c|c|c|}
\hline \multicolumn{4}{|c|}{$\begin{array}{l}\text { 1. Themes and items of administration related } \\
\text { satisfaction: }\end{array}$} \\
\hline Local administration & $\mathbf{N}$ & Mean & STD \\
\hline Administrative support to the job & 218 & 2.96 & 1.238 \\
\hline Techniques of giving feedback & 114 & 2.71 & 1.167 \\
\hline Policy of evaluation of a teacher & 212 & 2.44 & 1.169 \\
\hline Responsibilities of too much work & 205 & 2.70 & 1.132 \\
\hline $\begin{array}{l}\text { Getting sufficient time for family } \\
\text { home }\end{array}$ & 207 & 3.09 & 1.187 \\
\hline Total mean of 5 items & & 13.90 & \\
\hline
\end{tabular}

Table 7 showing the mean of local administration. It had 5 items with cut off value of 15 . Total achieved mean was 13.90. Total mean was much less than the cut off value, which indicated teachers high level of dissatisfaction in this theme.

Table 8: Distribution of mean score and SD of level of satisfaction with different items in relation to central administration. 


\begin{tabular}{|l|c|c|c|}
\hline Central administration: & N & Mean & STD \\
\hline Administrative policy & 218 & 3.23 & 1.141 \\
\hline Situation of chain of command & 218 & 3.22 & 1.159 \\
\hline Job security & 213 & 3.80 & 1.033 \\
\hline Political interference & 190 & 2.55 & 1.287 \\
\hline Promotion opportunity & 212 & 2.43 & 1.295 \\
\hline Transfer frequency & 189 & 3.19 & 1.385 \\
\hline Total mean of 6 items & \multicolumn{3}{|c|}{18.42} \\
\hline
\end{tabular}

Table 8 showing the mean score of satisfaction regarding central administration. It had 6 items with cut off value was 18. The total achieved mean was 18.42 . Total mean was slightly more than the cut off, which indicated teachers satisfaction in this theme.

Table 9: Distribution of mean score and SD of level of satisfaction with different items in relation to clinical teachers satisfaction.

\begin{tabular}{|l|c|c|c|}
\hline Clinical teachers satisfaction: & N & Mean & STD \\
\hline Scope for private practice & 135 & 3.23 & 1.240 \\
\hline $\begin{array}{l}\text { Feeling about frequent emergency } \\
\text { calls }\end{array}$ & 146 & 3.33 & 1.121 \\
\hline $\begin{array}{l}\text { Availability of relevant patients for } \\
\text { clinical teaching }\end{array}$ & 152 & 4.24 & .836 \\
\hline $\begin{array}{l}\text { Cooperation \& availability of } \\
\text { supporting staff }\end{array}$ & 152 & 3.54 & 1.144 \\
\hline Total mean of 4 items & \multicolumn{3}{|c|}{14.34} \\
\hline
\end{tabular}

Table 9 showing the clinical teachers satisfaction. This theme had 4 items with cut off value 12 . Achieved total mean was 14.34. Total mean was much more, which indicated teachers high satisfaction in this theme.

The mean values of the items were categorized into 4 groups on the perceived scores as $<2=$ highly dissatisfactory, 2-3 = dissatisfactory, $>3-4=$ satisfactory , and $>4=$ highly satisfactory. Mean score of none was $<2$. There were 18 items in the category of 2- 3 score. Within the theme 'teaching related responsibilities' the items included in this category were being creative and taking new challenges ; making contribution to educational development ; extent of support to the innovative ideas in teaching; supplies and maintenance of necessary educational material. Under the theme 'teaching environment' -one item was in this category. Regarding the items of 'work related satisfaction' current salary; opportunity for professional development of teachers and undue pressure at work place were in this category of 2-3. All the 5 items in 'facilities enjoyed' were within this score. The lowest score in this category was 2.23 which was related with other monitory facility and highest score was 2.96 which was related with administrative support to the teachers job.

There were 18 items in the category of $>3-4$. The lowest score was 3.09 related with 'getting sufficient time for family and home' and highest score was 3.94 which was related with 'relation with superiors'. Others were relation with others ,teacher student relationship, independence in work, responsibilities within teaching, attitude of student regarding their learning, supportive to the co- curricular activities, environment of institution and classroom, place of posting, current work, time for family and home, administrative policy, cooperation of supporting staff chain of command, job security, scope for private practice, feeling about frequent emergency calls .

The last group was $>4$ which indicates much satisfaction. In this category only 3 items were included. The score were 4.24 in relation with juniors, 4.25 in relation to relation with peers and 4.24 in relation to availability of patients for clinical teaching.

\section{Discussion}

Mean age of the teachers in this study was 42 years which is the active work force like the study done in Nigeria by Charles et al(2010) ${ }^{6}$ which was 42.8 years and $30-39$ years study done on Kuwait by Ibrahim ,Manal and Huda ${ }^{7}$.Over all satisfaction among doctors were not the same with Nigerian study (78.5\%) but study done in Kuwait overall job satisfaction was $61.8 \%$ and in this study it was $59.8 \%$. In a study in Kuwait revealed that, significantly higher the age and number of years working, the higher the job satisfaction. No significant difference in satisfaction for gender, specialty and marital status in study done in Pakistan by Khuwaja et al (2002) ${ }^{8}$ which has similarity with this study. Regarding work related satisfaction- level is slightly higher $(76 \%)$ regarding current work it self among the teachers in present study. Mean of which was 3.67. Mohr and Burgess (2011) 'studied that favorable job characteristics were associated with greater over all job satisfaction. Health organizations having emphasis on research activities, good relation with co workers, skill variety, professional identification may influence job satisfaction. Study done by Donald et al (2002) ${ }^{10}$ reported that, specialist and senior doctors were more dissatisfied with their pay. In this study only $37 \%$ teachers were satisfied with their current salary. Both senior and junior teachers were dissatisfied with the current salary which has similarity with the study done by Charles et al (2010) where among Nigerian doctors only $15.5 \%$ were satisfied with their salary. Opportunity for professional development of the medical teachers is not very high in Bangladesh. Suryanarayana and Luciana (2007) ${ }^{11}$ studied that only $36 \%$ teachers were satisfied with the opportunity for professional development and in present study also 36\% teachers were satisfied. Study ${ }^{12}$ showed that, in Germany teachers satisfaction related with opportunities for continuing education, job security, extent of administrative work, collegial relationship and access to specialized technology is high. In US sample, job security, interaction and relation

Bangladesh Journal of Medical Education 2011;2(1):18-22. 
with colleagues and management were important predictors of job satisfaction.

In the present study among 218 medical teachers $75 \%$ of the teacher were satisfied with one or other aspect of their job. According to one study ${ }^{13}$ satisfaction is a cognitive and perceptual process on teachers work condition. So, teacher may be satisfied with their work without much support. Whawo (1993) $)^{14}$ suggested that the higher the prestige of the job , the greater the job satisfaction. But many workers are satisfied with the least prestigious job. That is they simply like it what they do.

\section{Conclusion}

Job satisfaction is not high among medical teachers of Bangladesh. There were many factors related to satisfaction and dissatisfactions. Satisfaction regarding interpersonal relationship was high. Clinical teachers were highly satisfied. Dissatisfaction was highest in relation to current salary, teaching environment, opportunity for professional development of teachers, undue pressure at work place and facilities enjoyed other than salary. Political interference in recruitment, promotion, posting etc. was the most important cause for dissatisfaction. Satisfaction level of medical teachers was much less than average regarding local administration . Regarding central administration medical teachers were satisfied but not much.

\section{References}

1. Spector PE 1997, Job satisfaction: Application, assessment, causes, and consequences, p. 32, Sage publications. London.

2. Measuring Job Satisfaction in surveys- comparative analytical report 2007, European Foundation for the Improvement of Living and Working Conditions, website: www.eurofound.europa.eu

3. Perie M, Whitener S 1997, Job satisfaction among America's teachers: effects of work place conditions, background characteristics, and teacher compensation, Statistical analysis report, U s Department of Education, Washington DC, website; http://www. Ed.gov/NCES/

4. Ahmed I, Islam T 2011, Relationship between motivation and job satisfaction : a study of higher educational institutes, Journal of Economics and behavioral Studies, vol.3,no. 2, pp. 94-100.

5. Pillay R 2009, Work satisfaction of professional nurses in South Africa : a comparative analysis of the public and private sectors, Human Resources for health .vol.7 p. 15 website http://www.humanresourceshealth.com/content/7/1/15.

6. Charles O O, Mukaila AS, Bukola OO, Dantonjo EA 2010 ,Libyan J Med, no. 5 , pp. 4629-DOI: 10.4.176/ 091010 (reativecommons.org)

7. Ibrahim S Al-Eisa, Manal S Al-Mutar, Huda K AlAbduljalil 2005, Job satisfaction of primary health care physiciansat capital health region, Kuwait, Middle East Journal of Family Medicine, vol.3,no.3, retrieved on 3.8.2012 from mmutar@doctor.com.

8. Khuwaja AK, Qureshi R, Andrades M, Fatmi Z, Khuwaja NK 2002, Comparison of job satisfaction and stress among male and female doctors in teaching hospitals of Karachi, retrieve on 3.7.2012 mail: ali.khuwaja@aku.edu

9. MohrDC, Burgess JF 2011, Job Characteristics and job satisfaction among physicians involved with Veterans health administration, Academic medicine, vol.86. no. 8, pp.938-945

10. Donald E, William E, Thomas R, Eric S, Linzer M, Douglas J 2002, Physician job satisfaction, dissatisfaction, and physician turnover, The Journal of Family Practice, vol.51, no.7, pp. 51 - 6 .

11. Suryanarayana NVS \& Luciana MZ 2010, Teaching competency and teacher job satisfaction among secondary school teachers, www. teacher learner.com

12. Kinjerski V, Skrypnek B 2008, Increasing job satisfaction and organizational commitment and reducing turn over and absenteeism in long term care, journal of Gerentological Nursing, vol.34, no.10 ,pp.17-28.

13. Linn LS, Yager J, Cope D, Leake B 1986, Factor associated with life satisfaction among practicing internists, Med Care, vol. 24, pp. 830-37.

14. Whawo DD 1993, Educational Administration: Planning and supervision, p. 54, Judah Publication , Benin City. 